\title{
ASSESSMENT OF WOMEN'S ECONOMIC EMPOWERMENT IN THE RICE CULTIVATION SECTOR OF THE UPPER PUNJAB REGION, PAKISTAN
}

\author{
aSaira Akhtar, b,cShabbir Ahmad, bWu Huifang, cShakeel Imran, bChunyu Wang, 'Gulfam Hassan, dNazia \\ Tabasam, eKhalid Mahmood \\ a Department of Rural Sociology, University of Agriculture, Faisalabad, Pakistan. \\ ${ }^{b}$ College of Humanities and Development Studies, China Agricultural University, Beijing, China. \\ c University of Agriculture, Faisalabad, Sub Campus Burewala, Punjab, Pakistan. \\ ${ }^{d}$ Institute of Agriculture and Resource Economics, University of Agriculture Faisalabad, Pakistan. \\ e Benazir Income Support Program (BISP), F-Block, Pakistan Secretariate, Islamabad, Pakistan.
}

\section{ART I C L E IN F O}

\section{Article History}

Received: January 18, 2020

Revised: March 12, 2020

Accepted: April 27, 2020

\section{Keywords}

Women's Economic

Empowerment

Social Norms Diagnostic

Toolkit

Rapid Care Analysis Toolkit

Rice Cultivation

\section{A B S T R A C T}

The present study was conducted to identify and discuss the social norms, perceptions, and expectations which shape or constraint men's, and women's economic empowerment. The current study was conducted in the rice cultivation sectors of Sheikhupura and Gujranwala districts of the Punjab Province, Pakistan. A qualitative (cross-sectional) study was designed to get responses from the respondents of the targeted area. One tehsil was purposively selected from each district and sixty-five respondents (both males and females) were invited from 13 different villages of the above-mentioned tehsils. Focused Group Discussions (FGDs) were held for data collection activity in collaboration with the Doaba Foundation. A pre-defined interview guide based on Oxfam's Social Norms Diagnostic Toolkit and Rapid Care Analysis Toolkit was used to collect opinions from the respondents with the inclusion of various exercises. The major findings of the study revealed that most of the care work yielded by women ranging from the rice cultivation to the household chores go unacknowledged, because it is included in the total household income, and the rural women face discrimination in every sphere of life. The study concludes that to achieve women's economic empowerment, adequate wages, and safe working conditions, where they are protected from sexual and gender-based violence, must be ensured. The government should devise policies for the protection of women regarding discrimination and implement it in true spirit to fulfil the dream of the economic empowerment of women in Pakistan.

Corresponding Author: Wu Huifang

Email:wuhf@cau.edu.cn

(C) The Author(s) 2021.

\section{INTRODUCTION}

Women produce over $50.0 \%$ of the world's food (FAO, 2017) and comprise about $43.0 \%$ of the agricultural labor force around the globe (Quisumbing and Maluccio, 2000; Duflo, 2012; Maertens and Verhofstadt, 2013; Quisumbing et al., 2014; Singh and Chaudhury, 2016;
Mello and Schmink, 2017). Women's economic empowerment thus has a direct impact on the agricultural productivity and household food security (Harper et al., 2013; Sraboni et al., 2014; Yousaf et al., 2018), and as a result, it remains at the core of agricultural research and outreach practices in the 
developing countries (World Bank, 2012; French, 2014). The dilemma is that despite their (women) immense contribution, most of the care work ranging from the performance of household chores to the agricultural activities often goes unacknowledged due to the normative practices around the globe (Ferrant et al., 2014; Esquivel, 2014; Narayan, 2017; Blanc and Schuhl, 2018).

Agriculture constitutes the largest sector of Pakistan's economy. Directly or indirectly, $47.0 \%$ of the rural population including women depends on this sector for their sustenance (Rehman et al., 2017; Mughal, 2018). The contribution of the agriculture sector in the total gross domestic product (GDP) of Pakistan is about $19.5 \%$, and it accounts for half of the employed labor force. The share of women in the agricultural labor force in $68.0 \%$ as compared to their male counterparts (Irshad et al., 2018). The $68.0 \%$ women labor force mostly include illiterate women belonging to the menial class ${ }^{1}$ of the society. This menial class does not own their land, and they are forced to work on the lands of the feudal lords. The focus of this study is on the women who work in the rice cultivation sector belonging to the menial class of the society. As far as rice crop is concerned, Pakistan is the 10th largest rice producer, and 4th largest rice exporter around the globe, and it is the 3rd largest crop after wheat and cotton which is grown over $10.0 \%$ of the total cropped area in Pakistan (Memon, 2017), accounting for up to $8.0 \%$ of the total global rice trade. Rice forms around $9.0 \%$ of the country's export earnings, worth approximately $\$ 2$ billion US annually. Rice is a big source of income, but $70.0 \%$ of the households do not earn enough to meet their basic needs (Taj et al., 2018; Zaheer et al., 2018). The current research tries to explore the living income gaps in the rice cultivation sector and gender discrimination. Women, who are paid less than men, yet do more work, but their contribution is often going unacknowledged. The earnings of women are spent on food and maintenance of household spheres in most of the cases. Most of the care work yielded by women in the rice cultivation sector goes unacknowledged by their male counterparts despite the hard work they unleash in the scorching sunshine.

\footnotetext{
${ }^{1}$ The menial class include women of barbers, potters, drumbeaters, shoemakers $\&$ shoe menders, oil pressor, etc.
}

\section{Purpose and objectives of conducting the WEE assessment Rationale}

The approach to WEE (Women's Economic Empowerment) was rights-based, holistic, systemic, and aimed to challenge the mainstream economic (value chain) thinking, which discriminated or rendered women invisible and without power. Harmful social norms are considered one of the systematic barriers for women to meaningfully achieve economic empowerment. Deeply rooted social norms concerning gender roles and economic norms adversely affect women's rights. It determines whether they can forge their own pathway to empowerment or not. Oxfam's Social Norms Diagnostic Toolkit was developed to address discriminatory laws and practices which might curtail women's ability to break the cycle of poverty, access the resources she needs, and to benefit from economic opportunities. The above-mentioned Toolkit was composed of exercises which helped to identify and discuss social norms which curtain WEE in the rice value chain sector. While there is increasing recognition of women's valuable role in agriculture, they continue to assume greater responsibility for unpaid care work. The unpaid care work which includes care for the young, sick, and the elderly contributes to women's lack of control over time, limits their participation in the socioeconomic activities, and deprive them of access and benefit from the economic opportunities. The Rapid Care Analysis Toolkit consisted of exercises which aimed to bring about the recognition of unpaid care work. The Rapid Care Analysis Toolkit consisted of exercises which aimed to bring about the recognition of unpaid care work, develop evidence of the unique burden of the problematic care work, and to formulate practical solutions, which look beyond the household to include investments by the government, private sector, and other stakeholders in reducing and redistributing unpaid care work through improved care, infrastructure, and services. Since 2013, Oxfam's experience in using the RCA in different regions (over 20 countries) provides compelling evidence to successfully advance the advocacy for recognition, redistribution, reduction, and representation of unpaid care work. The Social Norms Study and Rapid Care Analysis (Unpaid Care Work) was conducted with the following objective: To identify and discuss the social norms, perceptions, and expectations which shape or constraint men's and women's economic 
empowerment. The following research paper has been divided into the following sections. The first section of this research article takes into consideration the introduction, purpose, and objective of conducting the WEE assessment. Review literature is the topic of discussion of the second section, the third section considers the materials and methods, the fourth section discusses the results and discussion, and the last section is dedicated to summarizing the entire research study including conclusion, suggestions, and recommendations.

\section{Review of Literature}

Several studies related to women's economic empowerment emerged during the last few decades. Among those, there are only a few studies which have examined the true concept of women's economic empowerment. Here, a review of some of those significant studies is presented.

In the international and national perspectives, the basic concept of women's economic empowerment is elaborated with various important studies like Weiss (2001), Khan (2007); Doepke and Tertilt (2011); Noureen and Awan (2011); Begum and Yasmeen (2011); Chaudhary et al. (2012); Kabeer (2012); Sohail (2020); Akter et al. (2017); Akhtar et al. (2018); Ojediran and Anderson (2020). The studies mentioned-above has analyzed the women's economic empowerment in different countries and regions around the globe, while some involved distinct indices with different variables. Khan (2007) analyzed women and paid work with a view to identifying where there were changes underway in this area which may play a role in leading to equitable gender relations in Pakistan in the long-term. Devi (2017) explored the relationship between women's economic empowerment, domestic violence, maternal nutritional status, and growth over 6 months in children aged 6 to 24 months in a rural and tribal community. Desai (2010) addressed the conceptual and methodological issues related to women's empowerment over the last 20 years in the key areas such as education, health, economic and political participation, and finally the best practices of state and non-state actors in empowering women. Doepke and Tertilt (2011)Doepke (2011) presented a debate on either the targeted cash transfers to women was good economic policy or not. Noureen and Awan (2011) had the purpose of their study to understand the importance of education for women in the Pakistani society and to examine the barriers and obstacles to higher education for women in Pakistan. Chaudhary, et al. (2012) tried to remove the misconception that Islam as a religion hinders the way of women empowerment. Kabeer (2012) was of the view that there was fairly strong empirical support for the claim that gender equality had a positive impact on economic growth. Chaudhary et al. (2012) attempted to investigate how consciousness/sensitization of women about their rights could be helpful for achieving the goal of women's empowerment? Sohail (2014) had a point of view that women still had difficulties in getting their due rights. Akter et al. (2017) pointed out that specific gender intervention frameworks were necessary to overcome gender gaps in the agriculture sector. Ojediran and Anderson (2020) identified in their respective paper that the promotion of women's economic empowerment as a development goal was based on a dual argument: social justice as an important aspect of human welfare and women's empowerment as a means to other ends.

Most of the research studies conducted by the earlier researchers generally focused on the economic empowerment of women in the government, semigovernment, private sector, and in the overall agricultural sector. The present research focuses on the illiterate rural women who render care work ranging from the household chores to the rice cultivation sector; and the ongoing social norms related to gender, the normative response to care work, and the contribution of women in the household spheres. The women and men who are selected as respondents in this study generally belong to the menial class of rural society.

\section{MATERIALS AND METHODS}

\section{Data information and salient features of the study area}

The Punjab province is geographically divided into three regions i.e., Upper Punjab, Central Punjab, and the Lower or Southern Punjab. The present study was conducted in the rural areas of the two districts i.e., Sheikhupura and Gujranwala. District Sheikhupura is bounded on the North by Gujranwala and Hafizabad districts, on the North-East by Narowal district, on the West and SouthWest by Nankana Sahib district, and on the East by Lahore district. Furthermore, District Sheikhupura is spread over an area of 3,280 square kilometers comprising of the following tehsils: Sheikhupura (51 
Union Councils), Ferozewala (21 Union Councils), Muridke (21 Union Councils), Sharaqpur (08 Union Councils), and Safdar Abad (11 Union Councils). For the study purpose, tehsil Muridke (21 Union Councils) was selected purposively. As far as district Gujranwala is concerned the district lies in between two main cities, in the North is the Gujrat and, in the South, there are Sheikhupura and Lahore. The Chenab river forms the northern boundary of the district. Beyond the river, it is bounded by Gujrat and Mandi Bahauddin districts, on the east by Sialkot district, on the south by Sheikhupura district, and on the West by Hafizabad district. Gujranwala district spreads over an area of 3,622 square kilometers comprising of the following seven Towns: Aroop Town, Khiali Shah Pur Town, Kamoke, Nandi Pur Town, Nowshera Virkan, Qila Daidar Singh Town, and Wazirabad. For this currant study, Kamoke town was selected purposively. Most of the population lives in the rural areas and mainly earns their livelihood through agriculture and other allied activities. It has 9 Markaz, 97 Union Councils, 800 Villages with a total area of 89, 2067 acres, out of which 78,3339 acres are cultivated.

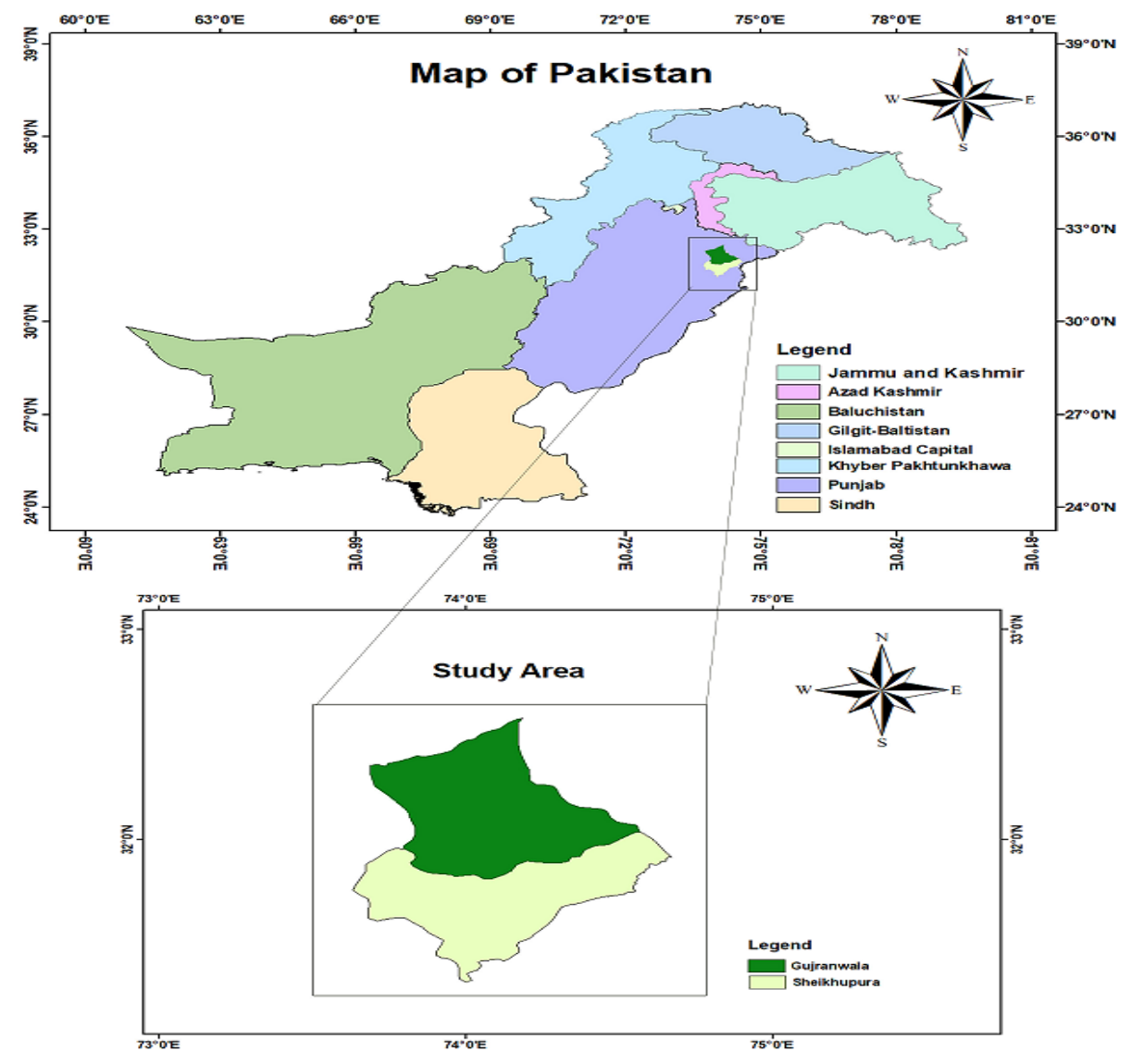

Figure 1. Geographical location of the study area.

\section{Research design}

Research design is a plan of study, which provides an overall strategic framework for data collection to answer the formulated research questions (Leedy, 1997; McMillan and Schumacher, 1984; Blanche et al., 2006). The present study was a qualitative (cross-sectional) study that was primarily designed to get the responses from the residents of the targeted area.

\section{Sampling techniques}

For data collection, a convenient sampling technique (non-probability sampling) was utilized throughout the entire research study. Tehsil Muridke was selected from district Sheikhupura, and Kamoke town was picked up from district Gujranwala conveniently. Sixty-five respondents (both males and females) were invited from 13 different villages, and they were transported to 3 
central villages where FGDs were held for data collection activity in collaboration with the Doaba Foundation ${ }^{2}$.

\section{Population of the study}

The respondents who were selected were of 35 to 55 years of age. Almost all the respondents were married and living in the joint families. Most of the respondents were landholders (varying in ownership of land while some were landless as well). Moreover, sixty-five men and women attended the FGDs belonging to 13 various villages.

\section{Scope and limitation}

Doaba Foundation arranged meetings with the respondents and provided with all the logistics and other support needed for this activity. The FGD venues were also set and managed by the above-mentioned Foundation. Due to the criticality of the time (harvesting season of the wheat crop), we had to confine the detailed activities into quick sessions. And the research team does not have any control over the criteria for the recruitment of the respondents. It was all decided and done by the Doaba Foundation.

\section{Data collection tools}

A pre-defined discussion guide was used to collect opinions of the respondents with the inclusion of various exercises. The research team had to confine themselves to collect information in as least time as possible due to the criticality of the harvesting season of wheat crop and unexpected heavy rains in the area.

Focused Group discussions were planned and executed in the targeted area. The study consisted of 5 FGDs with the community in three different villages of two districts of the rice-producing area i.e., Sheikhupura and Gujranwala. Initially, it was agreed upon that all of the FGDs would be held with the mix groups (a group

${ }^{2}$ Doaba Foundation works to improve the quality of life among disaster-prone communities through optimal utilization of resources. Using a rights-based approach, Doaba seeks to build capacity of communities, focusing on vulnerable groups, for community-led disaster risk management, incorporating the same in programs of sustainable development intervention. Doaba expands its influence through strategic partnerships and policy interventions. containing both men and women) as the methodology of "Rapid Care Analysis" suggests, but due to the cultural constraints, the FGDs had to be split between Male only (Male Exclusive) and Female Only (Female Exclusive) and a mixed gender group. Two FGDs were conducted with the female-only participants and two FGDs were held with the male only participants while one FGD was held with mixed-gender i.e., both Male and Female respondents in one group. Around sixty-five respondents (both males and females) were invited from 13 different villages, from the above-mentioned tehsils, and they were transported to three central villages, where FGDs were held for the data collection activity in collaboration with the Doaba Foundation. Two days' workshop on "RCA" was converted to a two hours FGD, so there were chances that some of the topics may not be given much attention as these were to be in a two-day workshop.

Two FGDs (one of the men and one of the women) and one FGD (Mixed Gender) were conducted in the villages 97/9-L and 96/6-R of the Sheikhupura district, respectively. Two FGDs (one of the men and one of the women) and one FGD (Mixed Gender) were conducted in the villages 16/1-L and 25/2-R of Gujranwala district, respectively. Eight exercises were conducted during the FGD process to get the responses. Underneath is the process for all these exercises one by one is explained briefly along with the methods adopted.

\section{Exercise \# 1: Identification of social norms relating to gender.}

The major objective of this exercise was to pinpoint current social norms related to gender as understood by group members.

\section{Method}

According to the discussion guide, groups were fragmented into men and women, but, since we had to conduct FGDs with Men Exclusive and Women Exclusive groups, so this exercise was done without splitting the group, yet one group which was a mixed group was split into two. Chart papers were handed over to the participants and they were asked to think about someone to whom the community would say is a 'good' woman or a 'good' girl, and someone to whom the community would say is a 'good' man or a 'good' boy. A discussion was started after getting the list of the traits developed by the participants. 
Exercise \# 2: Norms about the skills and value of care work.

An exercise was planned to identify the perceptions and norms about how different types of works are skilled/valued? And to introduce the idea that $\mathrm{HH}$ and care tasks are also considered as work.

\section{Method}

A list of types of care work was shown and discussed. The list consisted of occupations which many household heads were familiar with. Care work tasks and occupations were also part of the list. The participants were asked to rank how they perceive these tasks from the most skilled/valued to the least skilled/valued? And which activities are of men and women.

\section{Step 2: How have norms changed? What influences social norms to change?}

The objective of this step was to strengthen the understanding that norms have changed and will continue to change, and to what extent changing norms are significant.

\section{Method}

Building on the first exercise, participants were asked to reflect on a period that has contributed to changing norms (e.g., 1-2 generations) and discussed the change agents.

\section{Step 3: Who cares and why is care important?}

Two basic questions were discussed with the respondents to know about CARE. Those were: "What care is and why it matters?" and "Who provides care and how often?"

\section{Step 4: Time-use for women's and men's work.} Participants were given charts to recall and write their daily routine (time use pattern on a normal day). Two flip charts were used one for men and the other for women.

\section{Step 5: Distribution of care roles by gender and age.} Care roles discussed in Step 4 were discussed to know more about the distribution of the CARE roles and the gender and age-based assignment of these care roles.

\section{Step 6: Problems of care work.}

Problems faced by men and women in performing their responsibilities related to the CARE work were discussed in detail.

\section{Step 7: Mapping infrastructure and services.}

A map of infrastructure was drawn to get the picture of the area and to analyse how much time and effort one must put in to reach those amenities to perform those CARE roles?

Step 8: Solutions to reduce and redistribute care.

The solutions were discussed to reduce CARE work problems.

\section{RESULTS AND DISCUSSION}

Brief context of gender issues in the research area; highlighting the key barriers to WEE.

Women workers are freely engaged in the rice cultivation process. Their engagement is primarily in nursery raising, transplanting of rice, clearing of rice during seed preparation, and finally during the harvesting process. The on-going daily rate for female labor is PKR. 250/day and the average price for transplanting with a party of 5-6 persons is PKR. 2,2002,500 per acre. Children of both genders also work with women and men. Now, there is a trend to avoid providing such information openly because of recent child labor regulations in carpet and brick-kiln industries. The child labor in the agricultural sector and its implication for the health and education has already been investigated by Ahmad et al. (2020). The contractual labor is hired to do the job from the designated villages which provide the contract labor, and particularly most people are from the scheduled working classes ${ }^{3}$. Both these classes prefer providing labor force for rice transplantation as opposed to the harder tasks of working in factories or working in the brick-kilns. There are now contract growers of rice from these classes who lease out the land and undertake all operations in the rice production. The large farm owners have annual contracts, and they offer advance payments ${ }^{4}$. Infants and young children are left behind in

3 The scheduled working class include women of barbers, potters, drumbeaters, shoemakers \& shoe menders, oil pressor, etc.

${ }^{4}$ These advance payments sometimes serve as bounded labor. The labor force as already has mentioned that 
the villages in the custody of elderly women who are often responsible for babysitting and taking care of the children when females leave their villages for longer periods. Children are mostly neglected, and they often play alone in the streets with little or no supervision. Schooling amongst the two scheduled classes engaged in contract labor is minimal if at all it exists. There are many complaints of disease like fever, allergies, scabies, high/low blood pressure, and malnutrition amongst the women groups. No specialized facilities exist to take care of their needs. Some farmers offer transportation, food, and temporary residential facilities to the labor force. There are reports of sexual harassment in the fields including the use of inappropriate words, passing remarks, teasing, dirty joking, etc. At times advance payments have been reported from the middlemen or landowners who tend to make extraordinary favors in the form of reduced work hours, leave without a cut in wages, etc. While incidents of sexual harassment are often dealt within the community and only extreme cases come to the notice of the police. Most matters are dealt within the local panchayat ${ }^{5}$ system. Child labor is quite common during the rice transplantation, and young children work in the fields from dawn to dusk often missing their schools. Children skip school and join families to earn the extra cash and to fulfill the labor shortage during peak rice transplantation season. The results are in line with those of Ahmad et al. (2020) they had also pointed out in their respective research study that children were working in the agricultural sector of the Punjab province, Pakistan. No training facilities exist in the rice production system to impart skills within the industry or outside the industry. Thereby after rice transplantation, only low-level jobs are available for seasonal laborers such as weeding, picking, sorting, packing, and transportation of vegetables to the market. Women wages are seldom governed by labor laws. Likewise, labor employed in mills has a certain degree of job security, better compensation packages, set up work hours, and follow certain industry rules and regulations. Women, on the other hand, are at the mercy of the landowners who tend to collide in setting up labor

belong to the lower strata of the society. They lavish away the advance payments and then inclined to bounded labor

${ }^{5}$ The village governance system where most of the local disputes are resolved by the head of the village. wages. Women are paid almost half as compared to their male counterparts. There is no policy of benefits offered other than wages. Some companies offer transport, others offer lunch meals, some give a bag of rice during festive occasions, but no standardization in policies was noted. Women aspire to improve their lot and wages equality as their top-most proposals.

\section{Problems faced by the labor force}

The Focused Group Discussions (FGDs) presented insights into the major problems faced by women in the rice cultivation cycle. A synthesis of various responses is provided in Table 1.

\section{Key findings and analysis \\ Understanding social norms and identifying what social norms are related to gender perceptions at the household level?}

Women have less importance in the patriarchal society of Pakistan due to their lack of access to the sources of production (Akhtar et al., 2018; Ahmad et al., 2019). Moreover, they have less opportunity to get education, social mobility, decision-making, and rights of property ownership as compared to their male counterparts (Akhtar et al., 2018). The recognition of women at the household level is the symbol of respect if women hold a positive character in the society. These characteristics are not much important for men before marriage as compared to women. After marriage, women should be obedient and must be able to look after all the household chores. This is the prime responsibility of women which approximately all women had to fulfill in their respective houses. The responsibilities include being a good mother taking care of children, collecting firewood for fuel, cooking food, taking care of animals/milking, and supporting male members in the farm work.

\section{Perceptions at the farm level}

There is a normative practice that women will transplant rice saplings instead of men. This is because of the flexible stature of women, and the speedy work they render as compared to men. While the male workforce is less reliable in this regard. The respect of women as labor does not have admiration at all, while health care is absent during the plantation season of rice. Most of the male members were of the view that women were "used to" such type of vulnerabilities, and the health-related issues were temporary and would be 
recovered by the course of time. But this behavior needs attention because we have found that older women have lung cancer and backbone problems. Another dimension is access to health facilities, mostly women are not allowed to go outside of the village boundary, especially for health care facilities.

This is the responsibility of the male members of the family to take them to the health care facilities. If men are outstation, then women must wait for the household head for permission.

Table 1. Problems faced by women in the rice production sector.

\begin{tabular}{ll}
\hline Sr \# & Problems face by the labor force in the rice production and marketing system \\
\hline 1 & Low wages as compared to work. \\
2 & Lack of transportation. \\
3 & Harsh language used by the farmers. \\
4 & Long working hours. \\
5 & Sexual harassment of women and children. \\
6 & Delays in payment/wages. \\
7 & No social security. \\
8 & Poor living/working conditions. \\
9 & No updated technology/equipment. \\
10 & Low level of job satisfaction. \\
11 & Stager payment. \\
12 & No formal service contracts. \\
13 & No job training. \\
14 & No exposure to International best practices. \\
\hline
\end{tabular}

Table 2. The following are the list of the identified expected behaviour/role or characteristics of a good woman/good man by the community.

\begin{tabular}{|c|c|c|}
\hline & Woman Should be... & Man Should be... \\
\hline \multirow[t]{19}{*}{ Family } & Wise & Good for family \\
\hline & Educated & Obedient to parents \\
\hline & Having a positive character & Must keep a balance between mother and wife \\
\hline & Obedient to husband & Can run HH effectively \\
\hline & Dutiful & Cooperative with wife \\
\hline & Give time to children & Responsible \\
\hline & Take care of children & Refrain from lies \\
\hline & Head of household & Observing etiquettes \\
\hline & Take care of every relation & Refrain from Back biting and Slandering \\
\hline & Understand responsibilities of $\mathrm{HH}$ & Possess endurance and perseverance \\
\hline & Do all the chores of $\mathrm{HH}$ & Kind \\
\hline & Good mother, Good up bringer & Must know family obligations \\
\hline & Hard worker & Practical \\
\hline & Must take family along & Give due importance to all relations \\
\hline & Must serve parents and in laws & Do not use mobile phone \\
\hline & Good daughter, Good wife, Good mother & Positive thinking \\
\hline & Must stand with her husband & Educated \\
\hline & Respect of the guests & Good character \\
\hline & Must know the relatives & Long sighted / Visionary \\
\hline
\end{tabular}




\begin{tabular}{ll}
\hline Send kids to school & Courteous \\
Patience / Tolerant & Patience / Tolerant \\
Like cleanliness & Just, believes in equality \\
Respect of the elderly & possess good character \\
& Planning \\
& Must respect relations \\
\hline
\end{tabular}

\section{Perception at the societal level}

The acceptability and respect of gender roles in the society where men personally do not accept doing care work at the household level is a herculean task. If a male member in the patriarchal society of Pakistan renders a helping hand in the household chores, he is often ridiculed by the other male members of his community.
The roles and responsibilities of women are not limited to the performance of the household chores only, they are to render their services outside the household spheres also. The level of recognition they deserve is often denied to them. However, the care work male performs at the farm level is widely accepted as compared to women's household care work.

Table 3. Perception of the respondents about "good attitude with neighbors".

\begin{tabular}{ll}
\hline Society $\quad$ Good attitude with neighbors' & \\
\hline & Understand others pains and sorrows \\
& Example for the society \\
& Good at his business \\
& Philanthropist \\
& Refrain from using bad language \\
& Refrain from lies \\
& Etiquettes \\
& Refrain from Backbiting and Slandering \\
& Possess endurance and perseverance \\
& Kind \\
& Positive thinking \\
Good character \\
Long sighted / Visionary \\
Just, believes inequality
\end{tabular}

Table 4. Perceptions of the respondents about what should be their personal behaviors.

\begin{tabular}{lll}
\hline Personal & Offers Prayer & Honest \\
\hline Modest & Pious/religious \\
Observing Pardah (not-exposing herself) & Not jealous \\
Economizer & Bearing good moral character \\
Having good moral character & Not addict \\
Patient/Tolerant & Refrain from lies \\
Soft spoken & Observing etiquettes \\
Cleanly and sanitarian & Refrain from Backbiting and Slandering \\
& Patient and tolerant \\
& Kind \\
& Positive thinking \\
& Educated \\
& Courteous \\
& Just \\
\hline
\end{tabular}


Not greedy

Mostly, it is believed that Men and Women should behave according to the societal norms and values. The opinions of the respondents are given below.

"Aurat ghar ki sarbrah hoti hai aur mard kay zimay baahir kay kaam kaaj hotay hain" Translation: Woman is the chief runner of the family, and man is to look after the activities outside the household spheres.

The power of social expectations and the sense of 'belonging' is so strong that people act on norms even where these contradict their personal beliefs and attitudes.

For example, we interviewed some of the respondents who admitted, "They think that women are oppressed, and they should be helped in their day-to-day household chores, but they don't like to be labeled as "RUN MUREED", a bad connotation used to describe a husband who helps and do all the things with the will of his wife". The fear of society leads the people to follow the established norms, even if they do not agree to follow the beaten track the others are following. For instance, take the matter of female education, the people know that it is the basic right of females to be admitted in the educational institutions, but the established norms restraint them doing this right thing. Society is like a pressure cooker, it exerts pressure on the individual from all sides, sometimes cripples him to follow the path he does not like to follow.

"Larkion ko utni hi taaleem dilwani chahiyay jis say who achhay say ghar chala sakain. Hum nay konsa un say nokrian kawani hain" [Translation: A girl should be educated to the level to which she can run household properly. We do not want them to have jobs].

Due to the fear of sanctions, people are forced to follow the established norms of the society. Sometimes, the people are to follow norms that are contrary to the injunctions of religion, but the culture of this society endorse them. For instance, Islam encourages men to be helpful to their wives, but the cultural practices are contrary to this injunction, and if someone tries to follow it, he is ridiculed and termed as "female". That is why women are not helped by men in the execution of household chores, and most of the care work the females perform is not recognized even "work" altogether. Disobeying the societal norms can impact the livelihoods of the people in the negative direction; the people who go against local norms are socially excluded by the other members of the society, the people refuse to trade, marriage, and transactions of all kinds with the violators of the societal norms. It happened in societies where social cohesion and feelings of ethnocentrism are strong such as the rural societies where this research was conducted. The shift from joint family to nuclear family, the disappearance of social pressure from peers, and the transition from collectivism to individualism have made it easy for the people not to comply with the social norms.

\section{Understanding the change in social norms and the influence of change in the social norms on CARE. Changes in Norms of "CARE"}

Although, the "CARE" roles have not undergone much visible change, yet certain changes have been observed over the last two generations. Some of these are listed here: Men and women should both handle the family wellbeing. Women can get herself engaged in any type of employment (but not contrary to the socio-cultural and religious practices) with the permission of the household head to support her respective family. The ultimate decision-making still lies in the hands of the family head (male or female) in the rural areas instead of the urban ones. A gradual increase has been noticed in the non-compliance of such norms. Due to the opportunities of education, employment, and equal opportunities, women have not only acquired decisionmaking but are exercising more influence in the familial matters in the urban areas, but the situation is not up to the mark in the rural areas (Ahmed et al., 2021). A man who lends a helping hand to his wife in the household chores is still considered "a hen-pecked husband" particularly in the rural areas.

The norms of "care" are undergoing a considerable change for those women who are employed in the govt., semi govt., and private sectors. The illiterate women of the menial class are still performing not only in the household spheres but also in the rice cultivation sectors without proper recognition. Women can have the luxury of spare time if they are given the civic amenities. It will not only save their time, but they can become more 
productive and can earn more money also. The illiterate women who belong to the menial class undergo domestic violence if they refuse to perform care work. Hitting wives who refuse to perform CARE work properly is not considered a good attitude, but still hitting wives or female members is going on. Women's education is now considered good for the wellbeing of the family:

"Parhi likhi aurat matlab achhi tarbiat yafta nai nasal". [Translation: "An educated woman can produce a welltrained new generation"]

The factors affecting changes in the norms of "CARE" Education, electricity, well-equipped houses, washrooms at home, increased income levels, parents' socialization, media, and peer groups are the prime factors that affect changes in norms of "Care". Due to the provision of electricity, gas (or LPG), health, and educational facilities have changed the life patterns of women. Society is moving towards individualism, now, most of the people do not like to interfere in the issues of other people. Moreover, the shift from joint families to nuclear families have reduced the forced controls over the actions of the family members. Cell phones and media have affected the culture along with the CARE roles. The socioeconomic situation determines the CARE roles within the family. (Better socio-economic status means women can have assistance at home, they do not need to go out for farming and livestock activities).

Table 4. Norms about skills and value of work.

\begin{tabular}{|c|c|c|c|c|}
\hline \multicolumn{5}{|l|}{ Distribution of care activities } \\
\hline Activity & By Whom & Frequency & Skill & Paid /Unpaid \\
\hline Cooking & Women & Daily & Highly Skilled & Unpaid \\
\hline Taking care of family & Women & Daily & Semi-Skilled & Unpaid \\
\hline Taking care of budget & Women \& men & Daily & Semi-Skilled & Unpaid \\
\hline Taking care of the elderly & Women & Daily & Semi-Skilled & Unpaid \\
\hline Taking care of ill & Women \& men & As and when required & Semi-Skilled & Unpaid \\
\hline health & Women & Daily & Semi-Skilled & Unpaid \\
\hline Neighbors & Women & Daily & Semi-Skilled & Unpaid \\
\hline Education of the children & Women & Daily & Semi-Skilled & Unpaid \\
\hline Cleaning house & Women & Daily & Semi-Skilled & Unpaid \\
\hline Looking after $\mathrm{HH}$ well being & Women \& men & Daily & Skilled & Unpaid \\
\hline Pick \& drop of kids to school & Men & Daily & Semi-Skilled & Unpaid \\
\hline Taking kids to parks & Men & Twice a year & Semi-Skilled & Unpaid \\
\hline ploughing & Men & As and when required & Skilled & Paid \\
\hline Seeding & Men & As and when required & Skilled & Paid \\
\hline Transplantation & $\begin{array}{l}\text { Mostly Women } \\
\text { along with } \\
\text { children and } \\
\text { men }\end{array}$ & As and when required & Semi-Skilled & Paid \\
\hline Picking of fruits and vegetables & Women & As and when required & Semi-Skilled & Paid \\
\hline Harvesting (manual) & Women \& men & As and when required & Semi-Skilled & Paid \\
\hline Fodder & $\begin{array}{l}\text { Mostly men } \\
\text { along with } \\
\text { women }\end{array}$ & Daily & Semi-Skilled & Unpaid \\
\hline Selling of produce & Men & As and when required & Semi-Skilled & Paid \\
\hline Livestock handling and care & Women \& men & Daily & Skilled & Unpaid \\
\hline Washing clothes & Women & Daily & Semi-Skilled & Unpaid \\
\hline
\end{tabular}




\begin{tabular}{lcccc}
\hline Embroidery and stitching & Women & Daily & Skilled & Unpaid \\
Cleaning animal shed & Women & Daily & Semi-Skilled & Unpaid \\
Making dung cakes & Women & Daily & Semi-Skilled & Unpaid \\
Cutting wood for fuel & Men & As and when required & Unskilled & Unpaid \\
Collecting fuel wood & Women & As and when required & Unskilled & Unpaid \\
$\begin{array}{l}\text { Driving } \\
\text { First aid }\end{array}$ & Men & Daily & Skilled & Paid \\
$\begin{array}{l}\text { Bringing drinking water } \\
\text { Processing of crops for storage }\end{array}$ & Women \& men & As and when required & Highly Skilled & Unpaid \\
$\begin{array}{l}\text { Processing of crops (like wheat) } \\
\text { for grinding HH consumption }\end{array}$ & Women & Daily & Unskilled & Unpaid \\
\hline
\end{tabular}

Table 4 represents the types of work, skills, and the value of work associated with men and women. The above table shows that most of the tasks were unpaid for women but were paid for men. They must handle it in either case, skilled or not, as seen in the table. The results from the above table shows that women were normally highly skilled only in cooking, which was an unpaid family responsibility, harvesting was a part of their lives, so both men and women were performing their respective roles in it, for the family, it was also an unpaid work. Likewise, it does not matter if they are not skilled in cutting or collecting firewood for daily consumption, both genders must perform their roles. It is obvious from the above table that women were performing household chores, managing livestock, and working in the fields also; but most of the care work they yield was unpaid, not recognized, and without any credibility. It is noteworthy that after performing the household chores they are seen working in the rice fields working in the scorching sunshine without proper recognition because the income they earn from rice fields is included in the total household income. It is evident from the data that "care work" has historically been associated with women in day-to-day life activities. Perceptions and norms regarding work and tasks being performed are truly based on the gender-based norms of the division of work. In the labyrinths of the consciousness of the males, it is inscribed that women are the main runner of the household. They can manage the household spheres as effectively as they can. They need proper training which is not admired as LEARNED activity rather it is their duty. A split of some of the activities which differentiate paid work, unpaid work, and care work is given below in Figure 2. Men are responsible for the economic well-being of the family, and women are responsible for taking care of the family within the household spheres. Men's work is tougher as compared to women, and most of the activities are performed outside the household spheres. Men command supreme importance not only in the household but in the outside spheres also:

"Jo ghar main khanay ko laa kar daita hai baat bhi to ussi ki maani jaati hai" [Translation: "One who earns money for the family have upper hand in the household decisions"]

\section{"Aadmi baahir kay aur auratin ghar kay kaam karti hi achhi lagti hain"[Translation: "Men are made to work outside (economic activity) the household while women are for the household"].}

Table 4 and Figure 3 explored the workload of both genders. It may be seen here that men get more time to rest as compared to women as they perform more. Family care work is normally assigned to women, so they usually spend 10 hours a day in contrast to men's 2 hours of family care.

Typically, a rural woman works for 17 hours while a man works for 15 hours in a day. Men also have the privilege that they take time to go out, and they sleep at the noon after lunch and sometimes they sleep while being at fields or livestock shed. Most of the women's tasks are unpaid care work for the family. Although, she is involved in some economic activities like livestock management (inclusive of fodder, cleaning of the shed, fodder chopping, feeding, milking, etc.), yet her support in these activities is considered as "Helping Hand" or family labor, while these activities lead to add economic 
benefits for the whole family. But their contribution is considered as are unpaid.

"Aurat ka kaam aadmi kay kaamn main haath batana hai"[Translation: "Woman has to lend a helping hand to her husband"]

\section{How are care roles distributed by gender and age?}

Most of the care work is distributed among women and young girls, and they must do all the chores inside the home. Elderly women are to assign jobs to the younger members of the family and get things done in the manner they want.

"Buzarg khawateen apni bahoo baiteon ko kaam batatai hain aur un say woh kaam karwati hain, Iss tareeqay say woh un ki tarbiat bhi kar rehi hoti hain" [Translation: "Elderly women instruct younger ones which tasks are to be performed? And how those tasks are to be performed? By doing so they are also training the younger ones"]

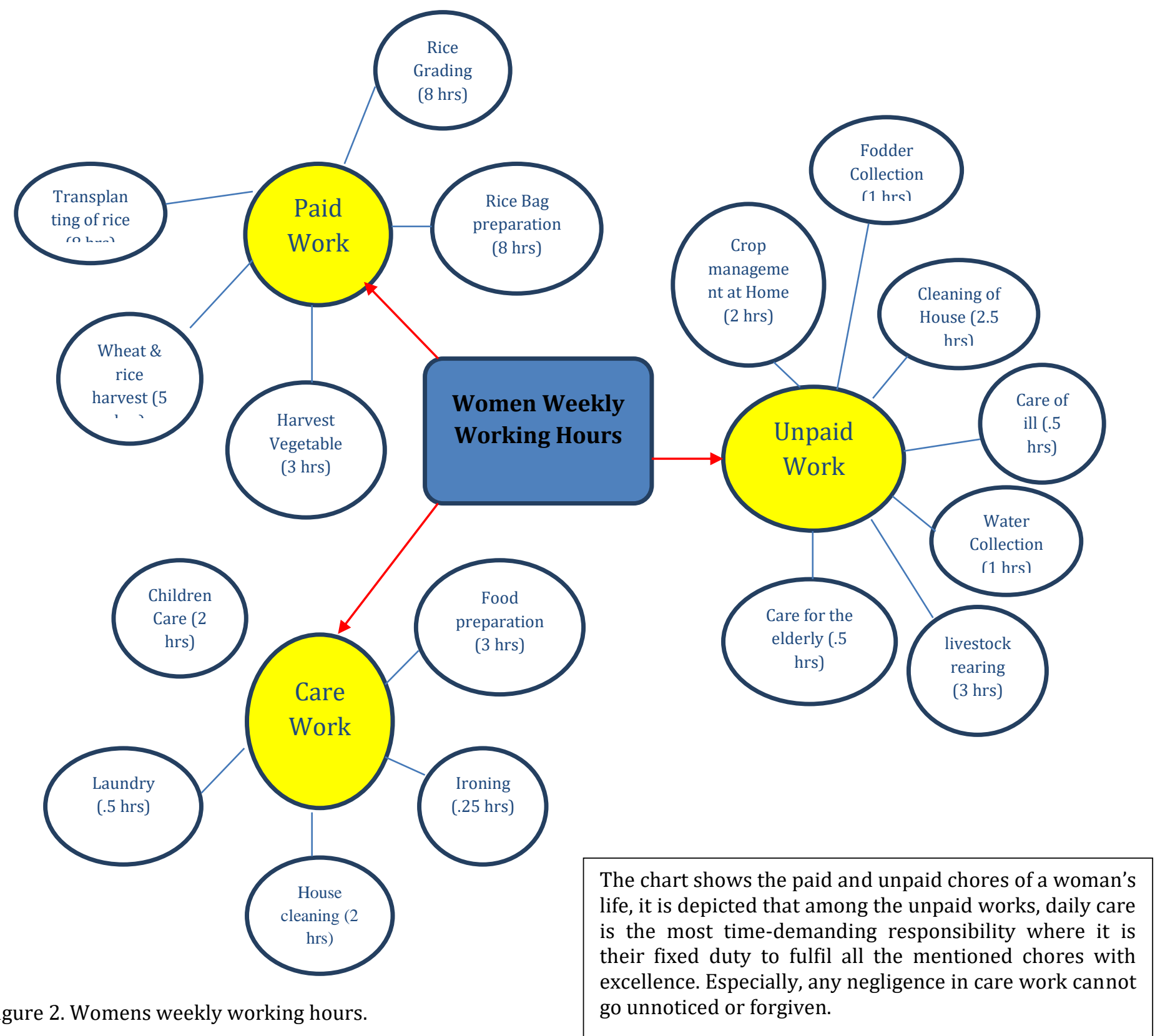


Inside the households:

\section{WOMEN}

1) Cooking

2) Cleaning of house

3) Laundry

4) Childcare

5) Ironing

6) Care of ill

7) Care of elderly

8) Processing of crops for storage

9) Preparing of stored food item for grinding etc.

\section{MEN}

1) Care of family

2) Looking after the matters of children outside home

3) Taking care of elderly

4) Take ill to the doctor.

\section{Outside the households:}

\section{WOMEN}

1) Collecting fuel wood

2) Preparing dung cakes

3) Brining drinking water

4) Cleaning of livestock shed

5) Transplanting (rice seedlings)

6) Harvesting of crops

7) Harvesting of vegetables and fruits like strawberries and peas

8) Bringing fodder and feeding animals

9) Milking
MEN

1) Ploughing

2) Harvesting

3) Transplanting

4) Marketing of harvest

5) Management of labor

6) Livestock management including fodder, watering and milking

This chart described that how men and women perform various chores in their daily routine. Both fulfil all the responsibilities in their assigned circle. While women also attend men while they arrive home after performing their activities out the household sphere. They need dinner, washed and ironed clothes, etc. on time. No matter what goes in the background. 
Table 5. A time-use pattern for men and women's work.

\begin{tabular}{|c|c|c|c|c|}
\hline \multirow[b]{2}{*}{ Time } & \multicolumn{2}{|c|}{ Men } & \multicolumn{2}{|c|}{ Women } \\
\hline & Main activity & Simultaneous activity & Main activity & Simultaneous activity \\
\hline $12: 00-1: 00 \mathrm{AM}$ & Sleep & & Sleep & \\
\hline $1: 00-2: 00$ AM & Sleep & & Sleep & \\
\hline $2: 00-3: 00 \mathrm{AM}$ & Sleep & & Sleep & \\
\hline $3: 00-4: 00$ AM & Sleep & & Sleep & \\
\hline 4:00 - 5:00 AM & Prayer & & Prayer & Prepare lassi \\
\hline $5: 00-6: 00$ AM & Livestock care & Milking & Livestock care & Fodder, milking \\
\hline $6: 00-7: 00 \mathrm{AM}$ & Livestock Care & & $\begin{array}{l}\text { Breakfast } \\
\text { preparation, serve } \\
\text { breakfast to kids }\end{array}$ & $\begin{array}{l}\text { Getting kids ready for } \\
\text { school }\end{array}$ \\
\hline 7:00 - 8:00 AM & Breakfast & & $\begin{array}{l}\text { Breakfast serves to } \\
\text { male and elderly }\end{array}$ & Utensils washes \\
\hline 8:00 - 9:00 AM & Farm management & $\begin{array}{l}\text { Fodder cutting from } \\
\text { fields }\end{array}$ & Cleaning of home & \\
\hline 9:00-10:00 AM & Farm management & & $\begin{array}{l}\text { Cleaning of livestock } \\
\text { shed and collection } \\
\text { of dung }\end{array}$ & Prepare dung cakes \\
\hline 10:00-11:00 AM & Farm management & & Fodder cutting & $\begin{array}{l}\text { Stitching, washing } \\
\text { clothes }\end{array}$ \\
\hline 11:00-12:00 AM & Farm management & & $\begin{array}{l}\text { Preparations for } \\
\text { lunch }\end{array}$ & Bringing water \\
\hline $12: 00$ - 1:00 PM & Lunch at home & & Serve lunch & \\
\hline $1: 00-2: 00$ PM & Prayer & & Serve lunch to kids & $\begin{array}{l}\text { Washing uniforms, } \\
\text { dishwashing }\end{array}$ \\
\hline $2: 00$ to $3: 00 \mathrm{PM}$ & Sleep & & Children care & \\
\hline $3: 00$ to $4: 00 \mathrm{PM}$ & Farm management & & $\begin{array}{l}\text { Cleaning of livestock } \\
\text { shed }\end{array}$ & $\begin{array}{l}\text { Collection of } \\
\text { fuelwoods }\end{array}$ \\
\hline $4: 00$ to $5: 00 \mathrm{PM}$ & Fodder chopping & Feeding animals & Animal care & $\begin{array}{l}\text { Helping kids in } \\
\text { homework }\end{array}$ \\
\hline $5: 00$ to $6: 00 \mathrm{PM}$ & Milking & & Dinner preparation & Milking of animal \\
\hline $6: 00$ to $7: 00 \mathrm{PM}$ & Free time & Visiting relative & Dinner preparation & \\
\hline $7: 00$ to $8: 00 \mathrm{PM}$ & Dinner & & $\begin{array}{l}\text { Serve dinner to } \\
\text { family }\end{array}$ & \\
\hline $8: 00$ to $9: 00 \mathrm{PM}$ & Friends time & Family time & Bedding & TV \\
\hline $9: 00$ to $10: 00 \mathrm{PM}$ & Sleep & & $\begin{array}{l}\text { Dish washing, } \\
\text { kitchen cleaning, } \\
\text { yogurt making }\end{array}$ & \\
\hline $10: 00$ to $11: 00 \mathrm{PM}$ & Sleep & & Sleep & \\
\hline $\begin{array}{l}11: 00 \text { to } 12: 00 \mathrm{Mid} \\
\text { Night }\end{array}$ & Sleep & & Sleep & \\
\hline
\end{tabular}




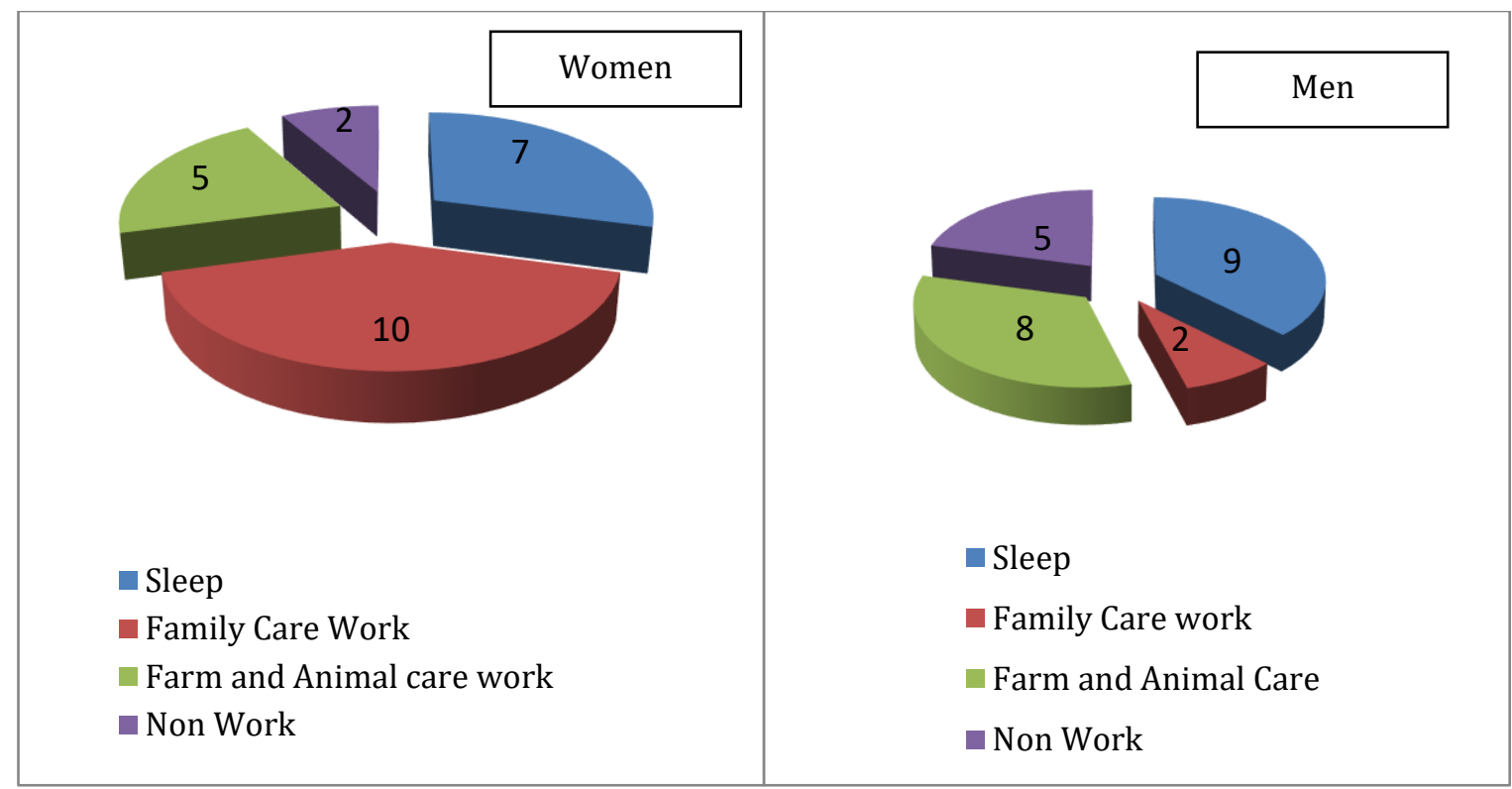

Figure 3. Distribution of a day (24 Hrs. Summed Up).

Identification of the problematic unpaid care activities

It is generally understood that care work is time consuming, laborious, unrecognized, and furthermore, it is considered an unpaid duty. The most problematic unpaid care works identified by participants were: Preparing meals (it involves burning dung cakes and fuelwood which generally affects the health condition of women).
Most of the women considered it a time consuming and a laborious activity), cleanliness of the streets (dirty water flowing freely in streets is hazardous to health), taking care of ill (time-consuming, also affects health as well), educating children (time consuming, requires money to get children educated, not easily accessible especially), and girl's high school and college education (fetching portable water because it is laborious and time consuming).

Table 6. Community mapping of infrastructure and services that support care work.

\begin{tabular}{|c|c|c|c|c|c|c|c|}
\hline $\begin{array}{l}\text { Water } \\
\text { supply }\end{array}$ & $\begin{array}{l}\text { Main } \\
\text { road }\end{array}$ & $\begin{array}{l}\text { High school } \\
\text { boys }\end{array}$ & $\begin{array}{l}\text { High school } \\
\text { girls }\end{array}$ & $\begin{array}{l}\text { Health } \\
\text { facility }\end{array}$ & $\begin{array}{c}\text { Vet. } \\
\text { hospital }\end{array}$ & Gas & Market \\
\hline
\end{tabular}

\begin{tabular}{lcccccccc}
\hline Village 1 & 0 & 0 & 0 & 0 & 0 & 0 & No & 0 \\
Village 2 & 1 & 0 & 5 & 5 & 5 & 5 & No & 1.5 \\
Village 3 & 0.5 & 0 & 7 & 8 & 10 & 7 & No & 10 \\
Village 4 & 1 & 0 & 9 & 10 & 11 & 11 & No & 11 \\
Village 5 & 1 & 0 & 9 & 10 & 11 & 11 & No & 11 \\
Village 6 & 0 & 0 & 10 & 10 & 10 & 10 & No & 5 \\
Village 7 & 0 & 0 & 11 & 10 & 11 & 11 & No & 5 \\
Village 8 & 0 & 0 & 0.5 & 0.4 & 10 & 10 & Yes & 0.1 \\
Village 9 & 0 & 0 & 1.5 & 1.5 & 11 & 11 & Yes & 10 \\
Village 10 & 0 & 0 & 3 & 3 & 9 & 9 & No & 9 \\
Village 11 & 0 & 0 & 5 & 5 & 10 & 10 & No & 10 \\
Village 12 & 0 & 0 & 4 & 4 & 8 & 8 & No & 8 \\
Village 13 & 0 & 0 & 3 & 3 & 9 & 9 & No & 9 \\
\hline
\end{tabular}

Distance in Kilometers 
Table 7. Community mapping of infrastructure and services that support care work.

\begin{tabular}{lcccccccc}
\hline & $\begin{array}{c}\text { Water } \\
\text { supply }\end{array}$ & $\begin{array}{c}\text { Main } \\
\text { road }\end{array}$ & $\begin{array}{c}\text { High school } \\
\text { boys }\end{array}$ & $\begin{array}{c}\text { High school } \\
\text { girls }\end{array}$ & $\begin{array}{c}\text { Health } \\
\text { facility }\end{array}$ & $\begin{array}{c}\text { Vet. } \\
\text { hospital }\end{array}$ & Gas & Market \\
\hline Village 1 & 10 & 0 & 5 & 5 & 10 & 10 & No & 5 \\
Village 2 & 30 & 0 & 30 & 30 & 35 & 35 & No & 20 \\
Village 3 & 15 & 0 & 40 & 40 & 40 & 40 & No & 60 \\
Village 4 & 20 & 0 & 60 & 60 & 50 & 50 & No & 60 \\
Village 5 & 20 & 0 & 60 & 60 & 50 & 50 & No & 60 \\
Village 6 & 5 & 0 & 35 & 35 & 35 & 35 & No & 30 \\
Village 7 & 10 & 0 & 35 & 35 & 40 & 40 & No & 30 \\
Village 8 & 5 & 0 & 10 & 5 & 30 & 30 & Yes & 10 \\
Village 9 & 5 & 0 & 10 & 10 & 40 & 40 & Yes & 40 \\
Village 10 & 5 & 0 & 15 & 20 & 35 & 35 & No & 35 \\
Village 11 & 5 & 0 & 20 & 20 & 40 & 40 & No & 40 \\
Village 12 & 5 & 0 & 20 & 20 & 30 & 30 & No & 30 \\
Village 13 & 5 & 0 & 20 & 20 & 30 & 30 & No & 30 \\
\hline
\end{tabular}

Time Spent (Minutes)

The Tables $6 \& 7$ given above show that most of the villages have insufficient facilities. So, it builds extra burden on the shoulders of women, as no gas supplies means that they must collect firewood or make dung cakes to cook food. No water supplies mean that they must fetch water for daily use, and the list goes on. While education facilities are also an issue, and here the norms also have their respective unique effect. It is obvious from the tables listed above that the provision of basic facilities of life can reduce the efforts of women of the rural areas, and they can save their valuable time from the household activities. Furthermore, the saved time can be utilized in income-earning activities. The earned income can be utilized in the improvement of different spheres of the household. It can save women from doing laborious activities in the right spheres.

Table 8. Identification and prioritization of the solutions.

\begin{tabular}{|c|c|c|c|c|c|c|c|c|}
\hline Facility & Priority & $\begin{array}{c}\text { Achievable } \\
\text { Y/N }\end{array}$ & $\begin{array}{c}\text { Financially } \\
\text { Feasible }\end{array}$ & $\begin{array}{l}\text { External } \\
\text { Support }\end{array}$ & $\begin{array}{c}\text { Socially } \\
\text { Acceptable }\end{array}$ & $\begin{array}{c}\text { Impact } \\
\text { (Time } \\
\text { saved) } \\
\text { Min }\end{array}$ & $\begin{array}{l}\text { Health } \\
\text { Benefit }\end{array}$ & Mobility \\
\hline $\begin{array}{l}\text { Provision } \\
\text { of gas }\end{array}$ & 1 & Yes & Yes & Govt support & Yes & 120 & Yes & $\begin{array}{l}\text { Restrict } \\
\text { mobility }\end{array}$ \\
\hline $\begin{array}{l}\text { Sewage } \\
\text { water }\end{array}$ & 1 & Yes & Yes & $\begin{array}{l}\text { Govt./commu } \\
\text { nity support }\end{array}$ & Yes & 30 & Yes & \\
\hline Hospital & 2 & Yes & Yes & Govt support & Yes & 40 & & \\
\hline High school & 2 & Yes & Yes & $\begin{array}{l}\text { Govt / } \\
\text { community } \\
\text { support }\end{array}$ & Yes & 20 & & \\
\hline $\begin{array}{l}\text { Potable } \\
\text { water }\end{array}$ & 3 & Yes & Yes & Govt support & Yes & 30 & Yes & \\
\hline $\begin{array}{l}\text { Link } \\
\text { village }\end{array}$ & & Yes & Yes & $\begin{array}{l}\text { Govt/commu } \\
\text { nity support }\end{array}$ & Yes & & & \\
\hline
\end{tabular}




\begin{tabular}{lccclcl}
\hline $\begin{array}{l}\text { Link to } \\
\text { market } \\
\text { from fields }\end{array}$ & 2 & Yes & Yes & $\begin{array}{l}\text { Govt/commu } \\
\text { nity support }\end{array}$ & Yes & Yes \\
$\begin{array}{l}\text { No proper } \\
\text { place for } \\
\text { dung cakes } \\
\text { making }\end{array}$ & 3 & No & No & Community & Yes & \\
Low wages & 1 & Yes & Yes & $\begin{array}{l}\text { Govt/commu } \\
\text { nity support } \\
\text { Govt./commu } \\
\text { nity support }\end{array}$ & Yes \\
$\begin{array}{l}\text { Girls } \\
\text { vocational } \\
\text { institute }\end{array}$ & 1 & Yes & Yes & & Yes \\
\hline
\end{tabular}

Table 8 is about the solution of the problems. The provision of Gas has an obvious impact and can save two hours of the daily tough routine of women. It means that they get more peace of mind to perform more efficiently. We see an improvement not only in the physical health but also in mental and psychological aspects. Water supplies may save their half an hour more of their daily routine; thus, it can be predicted that women's health gets improved if some basic problems are solved, either community takes an initiative or the government. The results of the study are in line with that of Qasim et al. (2018) that the provision of basic facilities of life to the women-folk can have a positive influence on the mental wellbeing of the women-folk.

\section{CONCLUSION AND RECOMMENDATIONS}

Social norms and gender stereotypes are indispensable factors that support the roles of women as caregivers, caretakers, etc., and they provide the context for the use of infrastructure and equipment which could affect the distribution of care handling. We believe that changing social norms and gender stereotypes favor the redistribution of unpaid care work between men and women. Assessment of social norms and care work is crucial in value chain business for resilience at the household and community level. It is important that opportunities such as equal wages, chances of technical and vocational education, nutritious food, decent work, and particularly employment at meso levels without any discrimination should be provided to the women of the menial class who are unleashing their maximum potential in the rice cultivation sector. Ensuring that women should have a workplace that can guarantees adequate wages and safe working conditions, where they are protected from sexual and gender-based violence is critical in Women's Economic Empowerment. Social norms are the key section for women's economic empowerment, underpinning, and contributing to the farm economy along with decent working conditions. There is a dire need to recognize the negative social norm which hinders the Women's Economic Empowerment not only in the performance of the household chores (particularly care work) but in the rice cultivation sector also. It has already been pointed out that the provision of basic utilities (provision of electricity, gas, electrical gadgets, gender-friendly agricultural tools, etc.) plays a significant role in the economic empowerment of women. It has been found that facilities like gas, electricity, gender-friendly technological interventions have a positive role in saving the precious time of women which can be spent in some economic activities, acquiring and polishing existing and new skills. In this study, the working hours of both the genders have been calculated and it was found out that women were working more than men but the tragedy was that it was household care work, which was usually unpaid and unacknowledged. The primary reason was wrongly believed social norms, and secondary reason included aware-lessness, inadequate facilities in terms of skill enhancement, absence in the decision-making process, low social status, etc. Wrongly believed and practiced social and cultural norms in the rural areas are responsible for creating hurdles in the women's economic empowerment not only in the rice cultivation sector but in other spheres of life also. Recognizing the impact of these hurdles on the economic enterprise, and its capacity to generate sustainable economic prospects for women is very much important. The reversing of the gender roles can result in a relocation of unpaid care work which may free up time for women to engage in 
economic activities. Thus, joint responsibility and redistribution of domestic work in families may be promoted, to give women free time for productive activities. The development of alternative technologies that address women's needs and the transfer of technology to both women and men is also suggested to redistribute the workload. For the WEE, women's small enterprises may be established along with proper training programs. Thus, investing in rural SMEs which promote women's economic empowerment may have its impact on a broader spectrum. Encouragement of investing in training, inputs, and technologies which are feasible for women and development of value chains of their output may include them into mainstream business to achieve the established WEE objectives. For this purpose, it is suggested that the vocational training centers should be directed to address the immediate problems the women are facing. By financing projects of renewable energy to facilitate women in their domestic tasks may ensure to have free time which they can invest in their respective empowerment by engaging themselves in productive and paid activities.

On the household level, there should be an awareness about the rights and responsibilities of both with mutual understanding. Electronic and print media should play a positive role in bringing the positive side of the social and cultural norms which hinder the WEE. The sociologists, political, and religious leaders can bridge the gap between the genders.

Market unions have little participation of women, so there should be a proper representation of women in the market unions. Children must be provided with the facilities of schooling, health, transportation, and entertainment at their doorstep so that women can work free of any anxiety related to the issues of the children. The social sectors such as NGOs, CBOs, community workers \& social activists need to focus on the issues pertaining to women not only in the rice cultivation sector but in the household affairs also.

\section{ACKNOWLEDGEMENTS}

This research article is the part of the Ph.D. Dissertation entitled "Livelihood Diversification Strategies among the Smallholders, and its Implications for Poverty Reduction: (A Sociological Study of the Punjab Province, Pakistan) of the second author.

\section{REFERENCES}

Ahmad, A., M. Iftikhar, B. Shahbaz, C. O. Igodan, K. Lechman and G. A. Khan. 2019. Assessment of skills gap among intermediaries of cotton supply chain in Punjab, Pakistan. International Journal of Agricultural Extension, 6: 186-91.

Ahmad, S., W. Huifang, S. Akhtar, S. Maqsood and S. Imran. 2020. An analytical study of child labour in the agriculture sector of the rural areas of central Punjab, Pakistan. Sri Lanka Journal of Social Sciences, 43: 21.

Ahmed, S., W. Huifang, S. Akhtar, S. Imran, G. Hassan and C. Wang. 2021. An analysis of urban sprawl in Pakistan: consequences, challenges, and the way forward. International Journal of Agricultural Extension, 8: 257-78.

Akhtar, S., S. Ahmad, H. Yousaf, A. Zafar and Q. A. Raza. 2018. Role of Women in Social and Agricultural Decision-Making in the Rural Areas of the Southern Punjab (Pakistan). International Journal of Humanities and Social Science, 5: 3438.

Akter, S., P. Rutsaert, J. Luis, N. M. Htwe, S. S. San, B. Raharjo and A. Pustika. 2017. Women's empowerment and gender equity in agriculture: A different perspective from Southeast Asia. Food Policy, 69: 270-79.

Begum, R. and G. Yasmeen. 2011. Contribution of Pakistani women in agriculture: productivity and constraints. Sarhad J. Agric, 27: 637-43.

Blanc, P. and C. Schuhl. 2018. Le temps d'accueil. Métiers de la Petite Enfance, 24: 37-38.

Blanche, M. T., M. J. T. Blanche, K. Durrheim and D. Painter. 2006. Research in practice: Applied methods for the social sciences Juta and Company Ltd.

Chaudhary, A. R., M. I. Chani and Z. Pervaiz. 2012. An analysis of different approaches to women empowerment: a case study of Pakistan. MPRA Paper 37784, University Library of Munich, Germany.

Desai, M. A. 2010. Hope in hard times: Women's empowerment and human development. UNDPHDRO Occasional Papers.

Devi, R. 2017. Gender equality: Women empowerment. GJRA -Global Journal for Research Analysis, 6: 141-43.

Doepke, M. and M. Tertilt. 2011. Does Female Empowerment Promote Economic 
Development? Policy Research Working Papers. The World Bank.

Duflo, E. 2012. Women Empowerment and Economic Development. Journal of Economic Literature, 50: 1051-79.

Esquivel, V. 2014. What is a transformative approach to care, and why do we need it? Gender \& Development, 22: 423-39.

Ferrant, G., L. M. Pesando and K. Nowacka. 2014. Unpaid Care Work: The missing link in the analysis of gender gaps in labour outcomes. Boulogne Billancourt: OECD Development Center.

French, G. M. 2014. Putting women and girls at the center of development. Science, 345: 1273-75.

Harper, S., D. Zeller, M. Hauzer, D. Pauly and U. R. Sumaila. 2013. Women and fisheries: Contribution to food security and local economies. Marine Policy, 39: 56-63.

Irshad, M. S., Q. Xin and H. Arshad. 2018. Competitiveness of Pakistani rice in international market and export potential with global world: A panel gravity approach. Cogent Economics \& Finance, 6: 1486690.

Kabeer, N. 2012. Women's economic empowerment and inclusive growth: labour markets and enterprise development. Discussion Paper No. 29. Centre for Development Policy \& Research, School of Oriental \& African Studies, University of London.

Khan, A. 2007. Women and paid work in Pakistan. Karachi: Collective of Social Science Research.

Leedy, P. D. 1997. Practical research: Planning and design Prentice Hall: New Jersey.

Maertens, M. and E. Verhofstadt. 2013. Horticultural exports, female wage employment and primary school enrolment: Theory and evidence from Senegal. Food Policy, 43: 118-31.

McMillan, J. H. and S. Schumacher. 1984. Research in education: A conceptual introduction Little, Brown.

Mello, D. and M. Schmink. 2017. Amazon entrepreneurs: Women's economic empowerment and the potential for more sustainable land use practices. Women's Studies International Forum, 65: 28-36.

Memon, N. A. 2017. Pakistani rice export industry unable to compete world marke, https://www.foodjournal.pk/2017/July-
August-2017/PDF-July-August-2017/Dr-NoorRice.pdf.

Mughal, M. A. Z. 2018. Rural urbanization, land, and agriculture in Pakistan. Asian Geographer, 36: 81-91.

Narayan, N. 2017. Contextualizing unpaid care work and women empowerment. International Journal of Applied Research, 3: 654-59.

Noureen, G. and R. u.-N. Awan. 2011. Women's Education in Pakistan: Hidden Fences on Open Frontiers. Asian Social Science, 7.

Ojediran, F. O. and A. Anderson. 2020. Women's Entrepreneurship in the Global South: Empowering and Emancipating? Administrative Sciences, 10: 87.

Qasim, M., S. Ahmad, S. Akhtar, S. Imran and K. N. Qureshi. 2018. Urban Population Behaviour and Knowledge Assessment about Water Quality, Consumption, and Conservation in Pakistan. Environment and Ecology Research, 6: 525-36.

Quisumbing, A. R. and J. A. Maluccio. 2000. Intrahousehold allocation and gender relations: New empirical evidence from four developing countries. FCND Discussion paper.

Quisumbing, A. R., R. Meinzen-Dick, T. L. Raney, A. Croppenstedt, J. A. Behrman and A. Peterman. 2014. Closing the Knowledge Gap on Gender in Agriculture Gender in Agriculture. Springer Netherlands. pp. 3-27.

Rehman, A., L. Jingdong, A. A. Chandio and I. Hussain. 2017. Livestock production and population census in Pakistan: Determining their relationship with agricultural GDP using econometric analysis. Information Processing in Agriculture, 4: 168-77.

Singh, K. R. and S. Chaudhury. 2016. Efficient technique for rice grain classification using back-propagation neural network and wavelet decomposition. IET Computer Vision, 10: 78087.

Sohail, M. 2020. Women Empowerment and Economic Development-An Exploratory Study in Pakistan. Journal of Business Studies Quarterly, 4: 9.

Sraboni, E., H. J. Malapit, A. R. Quisumbing and A. U. Ahmed. 2014. Women's Empowerment in Agriculture: What Role for Food Security in Bangladesh? World Development, 61: 11-52. 
Taj, S., S. Heaney-Mustafa, B. Chambers and R. Fitzgerald. 2018. Place-based Development: A Comparative Study of Gender Empowerment and Community Collaboration in Small Farming Households in Punjab, Pakistan. Asian Studies, 1: 26-32.

Weiss, A. M. 2001. Social Development, the Empowerment of Women, and the Expansion of Civil Society: Alternative Ways out of the Debt and Poverty Trap (Distinguished Lecture). The Pakistan Development Review, 40: 401-32.
World Bank. 2012. World Development Report 2012: Gender Equality and Development.

Yousaf, H., M. U. Zafar, M. O. Zafar, S. Ahmad and Q. A. Raza. 2018. Regional distribution of food security and its determinants across regions of the Punjab, Pakistan. Pakistan Journal of Agricultural Sciences, 55: 711-17.

Zaheer, R., S. Hussain and M. Nadeemullah. 2018. Agricultural Development And The Role of Women's Self- Employment In Pakistan. Pakistan Journal of Gender Studies, 16: 103-20. 